\title{
SPRAWOZDANIA SYTUACYJNE URZEDU WOJEWÓDZKIEGO ŚLĄSKIEGO ZA LATA 1933-1939 JAKO ŹRÓDLO DO AKTYWNOŚCI ZWIĄZKÓW MNIEJSZOŚCI NIEMIECKIEJ W WOJEWÓDZTWIE ŚLĄSKIM
}

\section{Ludność niemiecka na polskim Górnym Śląsku po roku 1922}

Rekonstrukcja państwa polskiego będąca następstwem rezultatów pierwszej wojny światowej napotykała, jak wiadomo, na różnego rodzaju przeszkody natury politycznej, militarnej i etnicznej. Ostatnio wymieniona okoliczność dała o sobie znać zwłaszcza przy zabiegach o włączenie do Polski Górnego Śląska. Obszar ten składał się z części Śląska Cieszyńskiego, należącego do chwili włączenia go do Polski na konferencji w Spa w 1920 r. do Austrii oraz z przyznanej Polsce w czerwcu 1922 r. wschodniej części Górnego Śląska, dotąd należącego do Niemiec. O ile na Śląsku Cieszyńskim zaistniała rywalizacja z Czechami, to niemiecki Górny Śląsk był przedmiotem walk aż trzech powstań, plebiscytu i walki politycznej jaką toczyła tamtejsza społeczność polska pod wodzą Korfantego ${ }^{1}$.

Pominąć można tutaj skomplikowaną i w równej mierze zasadną, co i sztucznie fabrykowaną argumentację zarówno polskiej, jak i niemieckiej strony, przemawiającą bądź to za pozostawieniem niepodzielonego Śląska w granicach państwa niemieckiego, bądź to przekazania jego polskojęzycznej części Polsce. Zaznaczyć jednak należy, że zarówno z racji geograficznych, jak i gospodarczych wschodnia część Górnego Śląska wpisywała się zasadnie w granice odbudowywanej Polski². Język i tradycja kulturowa dużej części jego mieszkańców stanowiły dodatkowy argument na korzyść strony polskiej.

* Sabina Bober - dr hab. historii, adiunkt w Instytucie Historii KUL, kierownik Pracowni Dziejów Mniejszości Narodowych w Europie Środkowej i Wschodniej, Instytut Historii KUL, e-mail: sabinabober@interia.pl

${ }^{1}$ M. Orzechowski, W. Korfanty, Biografia polityczna, Wrocław-Warszawa-Kraków-Gdańsk 1978, s. $182 \mathrm{nn}$.

${ }^{2}$ W. Zieliński, Polska i niemiecka propaganda plebiscytowa na Górnym Śląsku, Wrocław-Warszawa-Kraków-Gdańsk 1972, s. 216-226. 
Silna w owym czasie społeczność polska na Górnym Śląsku miała jednak w spadku tradycje państwowe pruskie i w porządku stworzonym przez Prusy, w którym pod wieloma względami czuła się zadomowiona. Język polski przechował się w środowisku rodzinnym, w kościele i w prywatnym obiegu. W życiu publicznym funkcjonował język niemiecki, który utrwalał się także wśród Górnoślązaków zdobywających wykształcenie średnie i wyższe. Język polski, a ściśle narzecze śląskie, nie był zatem silnym argumentem przemawiającym za przynależnością do państwa polskiego ${ }^{3}$. Gdy chodzi o duchowieństwo, to wprawdzie na terenie tym przeważali księża polscy, ale w ciągu dwudziestolecia sporo było także Niemców i liczba ich zmalała dopiero pod koniec lat trzydziestych ${ }^{4}$. Liczebność grup etnicznych stabilizowała się w pierwszym dziesiątku lat powojennych i według spisu ludności z 1931 r. wynosiła: w całym województwie śląskim 1.194.635 Polaków i 90.545 Niemców, w tym w części górnośląskiej województwa Polaków było 1.055.340 i Niemców 68.735. W części cieszyńskiej Polaków było 140.295, Niemców - 21.910. Ten sam spis ludności podaje liczbę katolików polskiego pochodzenia - 1.046, zaś Niemców - 149.000. Liczba ewangelików w tym czasie wynosiła 77.300, co stanowiło $5.59 \%$ ogółu ludności ${ }^{5}$.

Specyfika Górnego Śląska polegała nie tylko na skomplikowanych stosunkach etnicznych i ich proweniencji historycznej, co odgrywało niemałą rolę zarówno, gdy w grę wchodzi obrona niemieckiego status quo, a nawet $w$ wielu przypadkach irredenty po cichu inspirowanej z Rzeszy, a realizowanej przez mniejszość niemiecką na Śląsku, jak i polonizacji czy repolonizacji tych ziem. Jeszcze bardziej wpływowym czynnikiem był stan posiadania na Górnym Śląsku. Ludność polska kojarzyła się tam z elementem na najniższej półce układu społecznego, a więc bądź to rolnicza, albo w miarę rozwoju przemysłu, robotnicza. Jej liczebności nie odpowiadał podział dóbr, jakimi tam dysponowano. Po nastaniu władzy polskiej 75\% procent kapitału lokowanego w przemyśle i 85\% prywatnej własności ziemskiej były w rękach niemieckich. Wprawdzie polityka wojewody śląskiego Michała Grażyńskiego doprowadziła do spadku własności niemieckiej do $50 \%{ }^{6}$, ale $\mathrm{i}$ to nie odpowiadało potencjałowi niemieckiemu do właściwych proporcji, bowiem nacja ta stanowiła tylko 10-13\% ogółu ludności.

${ }^{3}$ Ks. B. Bogedain (1810-1860), działacz oświatowy, sufragan wrocławski jak mało kto zasłużył się dla języka polskiego w życiu kościelnym Górnego Śląska. Jednak tamtejszą ludność traktował jako Prusaków polskiego języka. Por. Z. Zieliński, Educatrix et Advocata. Wychowawca i Obrońca. Miejsce Kościoła w dziejach Narodu, Lublin 2014, s. 38.

${ }^{4}$ H. Olszar, Duchowieństwo katolickie diecezji śląskiej (katowickiej) w Drugiej Rzeczypospolitej, Katowice 2000, s. 205. W roku 1926 Niemcy stanowili wśród duchowieństwa diecezji 15,9 \%, a w $1938-8,5 \%$. W bezwzględnych liczbach odpowiednio 58 do 41 .

${ }^{5}$ Tamże, s. 196-197.

${ }^{6}$ M. Margielewicz, Problem świadomości zagrożenia ze strony Niemiec w społeczeństwie polskim na Górnym Śląsu w ostatnich latach II Rzeczypospolitej. „Wieki Stare i Nowe”, 1 (16) 2009, s. 265. Por. też M. Wardzyńska, Byt rok 1939. Operacje niemieckiej policji bezpieczeństwa w Polsce. Intelligenzaktion, Warszawa 2009, s. 21. Autorka podkreśla niewspółmierność niemieckiego stanu posiadania w Polsce w stosunku do liczebności niemieckiej mniejszości. 


\section{Regulacje prawne i zaplecze polityczne mniejszości niemieckiej}

Na korzyść Niemców w Polsce działało kilka okoliczności. Najpierw były to traktaty zabezpieczające im status daleko idącej niezależności. Niemal w całym okresie międzywojennym regulacją prawną określającą sytuację mniejszości niemieckiej na polskim Górnym Śląsku, podobnie jak mniejszości polskiej na niemieckim Górnym Śląsku była konwencja genewska z 15 V 1922 r. Regulowała ona takie zagadnienia, jak ochrona praw nabytych, wywłaszczenie, obywatelstwo i zamieszkanie, kwestie socjalne i gospodarcze. Nad przestrzeganiem norm stanowionych przez traktat czuwać miały Górnośląska Komisja Mieszana i Górnośląski Trybunał Rozjemczy ${ }^{7}$. Konwencja miała na celu zachowanie porządku prawnego, zastanego w momencie nastania rządów polskich, w odniesieniu do stanu posiadania i sytuacji osobistej mniejszości, w tym przypadku niemieckiej, co jednak nie wykluczało prawa i zdolności władzy polskiej do wprowadzania własnych regulacji prawnych, na ile tego wymagał ustrój państwa i jego potrzeby. Konwencja jednak zawierała elementy ochrony praw mniejszościowych, a przy tym w wielu punktach dopuszczała interpretację kierowaną korzyścią jednej ze stron. Ponieważ stroną windykacyjną była z reguły mniejszość niemiecka, rodziło to zrozumiałe dysonanse $\mathrm{z}$ administracją polską. Okazją do tego była $\mathrm{z}$ jednej strony niekonsekwencja polityki władz polskich wobec mniejszości niemieckiej, zwłaszcza w początkach lat dwudziestych ${ }^{8}$. Z kolei polityka prowadzona przez wojewodę Michała Grażyńskiego rządzącego na Śląsku od 1926 r. konsekwentnie zmierzała do repolonizacji Górnego Śląska, co aktywizowało środowiska niemieckie do silniejszej kontrakcji. Władze rządowe Republiki Weimarskiej, jak zresztą później także III Rzeszy, unikały wszystkiego, co mogłoby wskazywać na inspirowanie i wspieranie irredenty niemieckiej na Górnym Śląsku. Rzeczywistość była jednak zgoła inna, gdyż nie tylko finansowa pomoc płynąca z pozornie prywatnej instytucji Deutsche Stiftung, ale także działalność kierowanych z Rzeszy organizacji niemieckich stanowiły czynniki będące częścią polityki Niemiec skierowanej przeciwko Polsce.

Wojewoda Grażyński w sposób o wiele bardziej energiczny niż polskie władze rządowe, prowadził politykę zmierzającą do polonizacji, względnie repolonizacji Górnego Śląska. Działania te napotykały jednak na silną kontrakcję Niemców, dobrze zorganizowanych i posiadających prasę, stanowiącą nie tylko narzędzie propagandowe w obrębie Sląska, lecz urabiającą opinię wrogą Polsce poza jej granicami, a zwłaszcza stwarzającą preteksty do interwencji rządu niemieckiego. Miało to także znaczenie dla aktów odwetowych wobec mniejszości polskiej na niemieckim Górnym Śląsku.

W 1921 r, powstała Organizacja pod nazwą „Deutschtumsbund zur Wahrung der Minderheitsrechte“(DB). W tym samym roku w Katowicach powstał „Volks-

${ }^{7}$ M. Maciejewski, Prawne aspekty położenia mniejszości narodowych na Górnym Ślasku w latach 1918-1939, „Czasopismo Prawno-historyczne”, 65 (2013) z. 1, s. 255. Tekst Konwencji zob. K. Kierski, Ochrona praw mniejszości w Polsce, Poznań 1933, s. 116-129.

${ }^{8}$ B. Kucharczyk, O polityce wojewody śląskiego Michała Grażyńskiego wobec mniejszości niemieckiej na Górnym Ślasku, „Res Politicae”, 4 (2011) s. 191. 
bund” kierowany przez Otto Ulitza. Z kolei powstały w Bielsku „Deutscher National-Sozialistscher Verein für Polen" miał już orientację ruchu narodowosocjalistycznego i w połowie lat trzydziestych przekształcił się w „Jungdeutsche Partei”, będącą faktyczną ekspozyturą NSDAP w Polsce9. W 1934 r. w Rzeszy utworzono „Auslandsorganisation der NSDAP”. Była to placówka podlegająca Ministerstwu Spraw Zagranicznych. W terenie działały tzw. „Landesgruppen der NSDAP”, m.in. w Katowicach. Partia hitlerowska kładła wielki nacisk na funkcjonowanie jej ekspozytur wśród mniejszości niemieckich, angażując w szczególny sposób konsulaty. Także utworzona w 1936 r. „Volksdeutsche Mittelstelle” (VOMI) stała się centrum dyspozycyjnym dla grup mniejszościowych ${ }^{10}$. Obok ,Jungdeutsche Partei” najbardziej wpływowa była utworzona w 1934 r. „Deutsche Vereinigung" (Zjednoczenie niemieckie), początkowo w Poznańskiem i na Pomorzu, ale obejmujące całą mniejszość niemiecką w Polsce. Z tego środowiska wychodziły najczęściej interpelacje w sejmie czy nawet na forum międzynarodowym. Kierowana przez dr Eduarda Panta „Deutsche Katholische Volkspartei” miała na Śląsku znaczne wpływy i starała się przeciwdziałać agitacji nazistowskiej. Senator E. Pant, był wprawdzie orędownikiem praw przysługujących mniejszości niemieckiej w Polsce, ale zarazem głosił konieczność lojalności wobec Polski, co przekreślało go w oczach ruchu hitlerowskiego, zyskującego coraz większy wpływ na Niemców poza granicami Rzeszy ${ }^{11}$. Obok wymienionych organizacji niemieckich, na Górnym Sląsku istniało wiele placówek kulturalnych, kościelnych, sportowych, młodzieżowych, które stanowiły w łonie wiodących stowarzyszeń struktury pozwalające na dotarcie do szerokich warstw społecznych. Ruch mniejszościowy był w różnoraki sposób dotowany z Rzeszy, w pierwszym rzędzie przez Deutsche Stiftung, organizację będącą często przykrywką dla dotacji idących z kasy państwowej.

\section{Próby hamowania ekspansji niemieckiej}

Michał Grażyński został wojewodą śląskim w sierpniu 1926 r. W tym samym roku, 24 czerwca, pierwszy biskup diecezji śląskiej, August Hlond, od 1922 r. administrator apostolski Górnego Śląska, został arcybiskupem gnieźnieńskim i poznańskim oraz prymasem Polski. Hlond usiłował nawiązać poprawne stosunki z katolikami niemieckimi, ale jednocześnie polszczył administrację kościelną i nadawał duszpasterstwu znamiona polskie. Niemcy mieli mu za złe, że podkreślał swój patriotyzm polski i popierał jego manifestację w obrzędach kościelnych ${ }^{12}$. Grażyński w jakimś stopniu prowadził wobec mniejszości niemieckiej politykę podobną, co Hlond na płaszczyźnie kościelnej. Dążył on do zatarcia śladów panowania pruskiego, ale zarazem na boczny tor przesuwał żywe na Śląsku tendencje autonomiczne, nie kładąc należytego nacisku na Statut Organiczny Wo-

9 J. Lutosławski, Mniejszość niemiecka w Polsce jako instrument rewizjonistycznej polityki w latach 1918-1939. www.archivia.com.pl/.../mniejszosc-niemiecka-w-polsce-jako-instrument-rewizjonisty (dostęp: 20.07.2016).

${ }^{10}$ Wardzyńska, Byt rok 1939. Operacje niemieckiej policji bezpieczeństwa w Polsce, s. 22-23.

${ }^{11}$ Z. Zieliński, Kościót w kręgu rzeczywistości politycznej, Lublin 2003, s. 125-132.

${ }^{12}$ Tenże, Educatrix et Advocata, s. 37-62. 
jewództwa Śląskiego i znaczenie Sejmu Śląskiego. Był politykiem sanacyjnym i, choć nie był Ślązakiem, to jednak ze Śląskiem wiązał go udział w powstaniach śląskich i znajomość tamtejszych stosunków. Jednakże widział on Śląsk jako integralną, zrośniętą z Polską pod każdym względem dzielnicę, co nie odpowiadało idei autonomii Śląska, nieobcej części Ślązaków ${ }^{13}$.

Nie można zanegować dyktatorskich zapędów Grażyńskiego, ale faktem jest, że rządy przedmajowe i po części sanacyjne, nie miały jasno wytyczonej linii postępowania w stosunku do Śląska. Silna mniejszość niemiecka na Śląsku, stanowiła czynnik wpływający na relacje polsko-niemieckie, oddziaływując na forum międzynarodowym ${ }^{14}$. Generalną linią polityki rządu polskiego na Śląsku było niedrażnienie Niemców. Widać to było m.in. w hamowaniu inicjatyw polskich organizacji na Śląsku, jak np. Polski Związek Zachodni utworzony w 1934 r., w miejsce istniejącego dotychczas Związku Obrony Kresów Zachodnich.

Niemcy na Sląsku, tak jak i w innych częściach Polski, nie kryli nigdy swych celów rewizjonistycznych. Taki kierunek miała polityka Stresemanna, ale konkretne działania podjęła Rzesza od momentu przejęcia władzy przez Hitlera. Mniejszość niemiecka w Polsce, z małymi wyjątkami, widziała tu także swoją rolę, zwłaszcza, że hitlerowskie plany powiększenia niemieckiego Lebensraumu na wschodzie znajdowały poparcie w społeczeństwie. Legalna działalność Volksbundu na forum Sejmu Śląskiego szła w kierunku autonomii Śląska, co zbliżało ją do polskiej opozycji ${ }^{15}$. Wojewoda Grażyński miał zadanie utrudnione, gdyż, zwłaszcza po śmierci Piłsudskiego i zawarciu z Niemcami paktu o nieagresji w 1934 r. jego wysiłki, żeby ograniczać aktywność mniejszości niemieckiej były hamowane przez MSZ, a niechęć wojewody do aspiracji autonomicznych, dodatkowo narażała go na spór z polską opozycją. W 1935 r. miejsce Eduarda Panta w Senacie polskim zajął jawny hitlerowiec, Rudolf Wiesner, przywódca JDP. Wprawdzie Grażyński doprowadził do likwidacji „Nationalsozialistische Arbiter Partei” na Górnym Śląsku, ale nie był w stanie zneutralizować podziemie

${ }^{13}$ Biograf Grażyńskiego, Henryk Rechowicz w książce Wojewoda śląski dr Michat Grażyński, Warszawa 1988 akcentuje zwłaszcza związki Grażyńskiego z Piłsudskim i sanacją oraz rozdźwięki między nim a działaczami śląskimi, m.in. Wojciechem Korfantym.

${ }^{14}$ Margielewicz, Problem świadomości zagrożenia ze strony Niemiec $w$ spoleczeństwie polskim, s. 272-274 pisze: „W polskim życiu Górnego Śląska kwestia niemiecka po zakończeniu I wojny światowej zajmowała bardzo ważne miejsce. Spór polsko-niemiecki o władanie obszarem przyznanym Polsce nie zakończył się w 1922 roku. Nie pozwalała na to obecność mniejszości niemieckiej, liczniejszej niż wykazał to spis z 1931 roku, silnej ekonomicznie, dobrze zorganizowanej, chronionej przez Konwencję genewską i przedłużające ją układy z listopada 1937 roku. Wyczulenie na zagrożenie niemieckie podtrzymywała polityka rewizjonizmu zachodniego sąsiada Polski. W ostatnich latach przed II wojną światową narastało ono coraz mocniej. [...] W stosunkach polskoniemieckich po podpisaniu deklaracji [o nieagresji z 1934 r. - S.B.] nastąpił względny spokój, zaprzestano wzajemnych ataków prasowych, władze województwa śląskiego uległy naciskom płynącym z Warszawy, aby nie nadawać żadnego rozgłosu procesom działaczy Deutscher Volksbund für Polnisch Schlesien i Jungdeutsche Partei. Na poprawę stosunków wpływ miała nie tylko deklaracja z 26 stycznia 1934 roku, lecz również wypowiedzenie przez Polskę traktatu mniejszościowego oraz wystąpienie Niemiec z Ligi Narodów."

${ }^{15}$ Kucharczyk, O polityce wojewody śląskiego Michała Grażyńskiego, s. 192. 
hitlerowskie, które w tym czasie działało już na rzecz przyszłej agresji. Pozorne zmniejszenie napięcia między Polską a Niemcami po 1934 r., trwające zresztą tylko do 1937 r., kiedy wynikła sprawa przedłużenia Konwencji genewskiej, nie umniejszało niebezpieczeństwa ze strony mniejszości niemieckiej na Śląsku ${ }^{16}$. Grażyński mógł tylko w czerwcu 1939 r. wezwać Wiesnera, uświadamiając mu jego odpowiedzialność za wrogą wobec Polski działalność JDP. Ten jednak zbył zastrzeżenia wojewody, powołaniem się na statut tej organizacji ${ }^{17}$.

Niezależnie od kierunku polityki mniejszościowej rządu i władz lokalnych na Górnym Śląsku, agendy mniejszości niemieckiej budziły żywe zainteresowanie w Warszawie i Katowicach, co wyrażało się ich inwigilowaniem, skrupulatnym analizowaniem wyników tej działalności i reagowaniem władz lokalnych na wszelkie pojawiające się nieprawidłowości. Ślad tej działalności mieści się w tzw. sprawozdaniach sytuacyjnych na ogół sporządzanych każdego miesiąca przez władze wojewódzkie, konkretnie Wydział Spraw Wewnętrznych.

\section{Sprawozdania sytuacyjne jako źródło do działalności mniejszości nie- mieckiej na Górnym Śląsku ${ }^{18}$}

Wiadomości zawarte $\mathrm{w}$ sprawozdaniach pochodziły z różnych źródeł. Najczęściej były to raporty policyjne, rzadziej i tylko w przypadkach odnoszących się do sfery cywilnej, kontrwywiadu. Do tego dochodziły materiały powstałe w trakcie czynności służbowych różnych szczebli władzy terenowej. Bardzo istotną część w sprawozdaniach sytuacyjnych stanowiły analogiczne sprawozdania sporządzane przez starostwa. Tylko w przypadkach szczególnych sięgano do raportów władz niższych, np. gmin. Sprawozdania sytuacyjne były na ogół obszerne, a sprawy mniejszościowe, którym tutaj poświęci się wyłącznie uwagę, stanowiły ich fragment o zróżnicowanej objętości, zależnie od toczących się wydarzeń. Znaczne miejsce zajmowała w nich prasa, która była w owym czasie głównym narzędziem propagandowym.

Od chwili dojścia Hitlera do władzy, zmienił się sposób działania mniejszości niemieckiej. Już jednak w przededniu tego wydarzenia, odczuwało się na Śląsku

${ }^{16}$ Wojewoda Grażyński był zdecydowanie przeciwny przedłużaniu Konwencji, uważając, że bez formalnego porozumienia łatwiej można będzie okiełznać apetyty mniejszości. Rząd zadecydował inaczej, wydając wspólnie z Niemcami deklarację o wzajemnej ochronie 5 XI 1937 r. mniejszości narodowych, co z kolei wiązało ręce Grażyńskiemu w stosunku coraz śmielej sobie poczynającej mniejszości niemieckiej na Śląsku. Por. Margielewicz, Problem świadomości zagrożenia ze strony Niemiec w społeczeństwie polskim, s. 276.

${ }^{17}$ Kucharczyk, O polityce wojewody śląskiego Michała Grażyńskiego, s. 193, 195, 198.

${ }^{18}$ Sprawozdania sytuacyjne Urzędu Wojewódzkiego, Wojewódzkiej Komendy Policji i niektórych innych placówek władz państwowych znalazły się w obszernej pracy Deutsche und Polen zwischen den Weltkriegen. Minderheitssituation und Volkstumskampf im Grenzgebiet. Amtliche Berichterstattungen aus beiden Ländern 1920-1939, opr. M. Niendorf, P. Hauser, Monachium i in. 1997. W niniejszym artykule chodzi o wypreparowanie z obszernych i obejmujących wszystkie dziedziny życia sprawozdań sporządzonych przez Urząd Wojewódzki Śląski tych informacji, które dotyczyły celu i rodzajów aktywności mniejszości niemieckiej na Górnym Śląsku od chwili przejęcia w Niemczech władzy przez Hitlera. 
narastający ton windykacyjny w wypowiedziach Niemców na Górnym Śląsku. Poseł na Sejm Śląski Otto Ulitz, przywódca „Volksbundu” stale interpelował w sprawie rzekomych krzywd Niemców. Nawet Pant podkreślający lojalność swej partii wobec władzy polskiej dopominał się o więcej swobód dla Niemców, aby uwiarygodnić w ich oczach państwo polskie ${ }^{19}$. W sprawozdaniu z $1931 \mathrm{r}$. scharakteryzowano powstały w styczniu 1931 r. „Deutscher Kulturverband”, szczegółowo wyliczając jego znaczne osiągnięcia. Z kolei Pant w czasie walnego zgromadzenia „Verband deutscher Katholiken” podkreślał konieczność liczniejszego pozyskiwania młodzieży ${ }^{20}$.

Konstruktywny głos w sprawie zwalczania bezrobocia z wezwaniem do organizowania społecznej pomocy ze strony zarządu głównego „Deutscher Katholischer Voksbund”, pojawił się w czasie zebrania zarządu 18 czerwca 1931. Główne oczekiwania kierowano jednak pod adresem rządu ${ }^{21}$.

„Katholische Volkszeitung”, lojalna wobec władz i społeczeństwa polskiego, w szeregu artykułów podjęła krytykę działalności niektórych organizacji mniejszościowych ${ }^{22}$.

Sprawozdanie ze zjazdu Deutsche Parte ${ }^{23}$ w Bielsku w dniu 9 sierpnia $1931 \mathrm{r}$. Odnotowano polemikę DKV i Panta na łamach prasy niemieckiej dotycząca celów i metod działania mniejszości niemieckiej na Górnym Śląsku. Zaniepokojenie mediów niemieckich frondą powstałą wskutek ujawnionej różnicy zdań przywódców politycznych ${ }^{24}$. Zaistniała sytuacja na Górnym Śląsku, miała niewątpliwie swe źródło w przenikaniu do mniejszości niemieckiej coraz silniejszego NSDAP.

Sprawozdanie z 21 lutego 1932 r. poświęcone jest w części traktującej o mniejszości niemieckiej Pantowi i DKV. Przy czym główny akcent położono na dynamikę wewnętrzną organizacji katolickich, zwłaszcza stanowych i społecznych. Uwypuklono pomoc charytatywną świadczoną przez to środowisko. Odcinano się od opozycji mającej podłoże polityczne, natomiast podkreślano potrzebę opozycji „rzeczowej” mającej na celu poprawę sytuacji mniejszości niemieckiej w zestawieniu z ogólnym położeniem w kraju ${ }^{25}$.

Zauważono pogłębianie się konfliktu między DKV, DP i „Jungdeutsche Partei” (JDP) w 1932 r. W sprawozdaniu zauważono, że obie ostatnie partie wyraźnie

${ }^{19}$ Wojewódzkie Archiwum Państwowe w Katowicach (dalej: WAPK) Urząd Wojewódzki Śląski (dalej: UWŚl.), sygn. 571. Sprawozdanie sytuacyjne z I-VI 1931, k. 56.

${ }^{20}$ Tamże, k. 151-152.

${ }^{21}$ Tamże, k. 218.

${ }^{22}$ Tamże, k.21. Sprawozdania sytuacyjne z VII-XII 1931.

${ }^{23}$ Deutsche Partei (DP) powstała w sierpniu 1922 r. ze zjednoczenia Deutschnationale Volkspartei, Deutsche Volkspartei i Deutsche Demokratische Partei. Organem jej była „Kattowitzer Zeitung", Dysponowała doświadczonymi kadrami, wywierała silny wpływ na Volksbund, a szef tej partii Otto Ulitz należał do DP. Jej członkowie to przeważnie protestancka burżuazja. Por. Deutsche und Polen zwischen den Weltkriegen, s. 970.

${ }^{24}$ WAPK, UWŚl. Sygn. 572, s. 49-56 i 79.

${ }^{25}$ Tamże, sygn. 573. Sprawozdanie sytuacyjne z 1932 r., k. 52-56. 
ulegały wpływom hitlerowskim i pracują nad zaszczepieniem ich wśród mniejszości niemieckiej ${ }^{26}$.

Rozdźwiękowi w łonie mniejszości niemieckiej na Górnym Śląsku poświęcone są dalsze sprawozdania z 1932 r. Jednocześnie władze wojewódzkie akcentują siłę i wpływy DKV, działającej poprzez liczne organizacje kulturalne i charytatywne, a także wychowawcze. Szereg artykułów na temat wychowania wyraźnie neutralizuje zasady wychowawcze hitleryzmu przenoszone z Rzeszy na teren Górnego Śląska. Prasa katolicka („,Katholische Volkszeitung”) bije na alarm z powodu zatruwania młodzieży jadem nienawiści do Polski i Polaków przez ośrodki nacjonalistyczne ${ }^{27}$.

Na początku 1933 r. w sprawozdaniu sytuacyjnym odnotowano inicjatywę Katholischer Jugend-und Männerverein planującego organizowanie wśród swych członków ochotniczych drużyn roboczych mających złagodzić skutki bezrobocia. Jednocześnie wpłynęły skargi na uchwaloną w 1932 r. ustawę o stowarzyszeniach $^{28}$. Władze DKV żywiły nadzieję, że episkopat będzie interweniował u rządu, celem złagodzenia nowej ustawy w stosunku do stowarzyszeń katolickich. Dla stowarzyszeń niemieckich w nowej ustawie groźne były postanowienia artykułu 6 mówiące, że zakazuje się tworzenie stowarzyszeń przyjmujących zasadę bezwzględnego posłuszeństwa członków wobec władz stowarzyszenia, oraz łączenie w stowarzyszeniu celów wychowania fizycznego, gimnastycznych lub sportowych $\mathrm{z}$ celami politycznymi ${ }^{29}$. Wymienione postanowienia uderzały zwłaszcza w organizacje niemieckie w Polsce, dla których stowarzyszenia gimnastyczno-sportowe bywały, zwłaszcza w ostatnich latach przed wybuchem wojny, przykrywką dla uprawiania tzw. Wehrsport - sportów obronnych, czyli przygotowania do służby wojskowej.

Pant i DKV aktywizują się przed wyborami samorządowymi w 1934 r., które są ostatnimi przed wygaśnięciem Konwencji Genewskiej. Podejmowana próba zmiany na stanowisku prezesa Volksbundu nie udała się. Planowano zastąpić księcia pszczyńskiego Hansa Heinricha von Pless, protestanta, katolikiem hrabią Henckel von Donnersmarkiem ${ }^{30}$.

W sprawozdaniu z kwietnia 1933 r. stwierdza się nasilenie się sympatii dla ruchu hitlerowskiego, co śledzi się na łamach „Kattwitzer Zeitung” i „Oberschlesischer Kurier" (organ partii Centrum) w toczonych tam polemikach świadczących o tym, że opcje polityczne w obozie katolickim zaczynają się różnicować. Wpływały na to zarówno wydarzenia w Niemczech, jak i tendencje w kierunku konsolidacji ruchu niemieckiego wobec władz polskich ${ }^{31}$.

${ }^{26}$ Tamże, k. 80.

${ }^{27}$ Tamże, Sprawozdanie VI-VII 1932, k. 160, 190, 220, 247. Podobna tematyka sprawozdania z października 1932, k. 200-391.

${ }^{28}$ Tamże, sygn. 574, k. 32.

${ }^{29}$ Dziennik Ustaw 1932 nr 94, s. 1947, poz. 808 Rozporządzenia Prezydenta Rzeczypospolitej z dnia 27 X 2932. Prawo o stowarzyszeniach.

${ }^{30}$ WAPK, UWŚl. Sygn. 574, k. 116-117 i k. 65

${ }^{31}$ Tamże, k. 142, 148. 
W marcu 1933 r. odnotowano w sprawozdaniu wzrost liczby członków DKV i utwierdzenie się autorytetu Panta ${ }^{32}$.

W sprawozdaniu z maja odnotowuje się ostry konflikt między „Volksbundem” na czele z Ulitzem a DKV, na czele z Pantem. Przedmiotem sporu jest problem przewodzenia mniejszości niemieckiej. Partie będące pod wpływem narodowego socjalizmu (DP, JDP) zdecydowane są pozbawić katolików wpływu na postawę mniejszości niemieckiej. Pant stawia na jednej płaszczyźnie bolszewizm, faszyzm i hitleryzm jako siły mające na celu zniszczenie chrześcijaństwa, a osobę Ulitza charakteryzuje jako przywódcę prowadzącego Niemców śląskich do hitleryzmu, na zasadzie stosowanej już w Rzeszy Gleichschaltung ${ }^{33}$.

Sprawozdanie z lipca 1933 r. stwierdza mobilizację DKV, której przywódca, Pant, wobec silnej infiltracji hitlerowskiej, decyduje się na rozszerzenie zasięgu swej partii także na ewangelików i znajdujących swe miejsce w partii o nazwie „Deutsche Christliche Volkspartei” (DChVP). Niemiecka publicystyka („Der Oberschlesischer Kurier”) zaprzecza doniesieniom prasy polskiej, jakoby wszyscy Niemcy na Śląsku znaleźli się pod wpływem Hitlera, oskarżając stronę polską o wspieranie tym sposobem propagandy hitlerowskiej. Z kolei „Katolische Volkszeitung" (nr 101) stwierdza, że cała mniejszość niemiecka znalazła się pod komendą Hitlera, a „Kattowitzer Zeitung” głosi wprost ideologię Hitlera. Gazeta powtarza pogląd głoszony przez Panta, że kto chce być obywatelem polskim musi zwalczać hitleryzm, który wszystkim inaczej myślącym niesie zagładę. Jako przykład daje bankructwo socjaldemokratów na Śląsku ${ }^{34}$.

Sterowana z Rzeszy akcja unifikacyjna (Gleichschaltung) wszystkich ugrupowań mniejszościowych pod egidą „Deutsche Partei” napotkała w sierpniu 1933 r. na zdecydowany opór Panta, który także uznał za konieczne jednoczenie się grup przeciwnych Hitlerowi na bazie DChVP. Pant określił też charakter działania w ramach swego programu, stwierdzając:

Nie możemy zajmować tylko stanowiska obronnego, naszym celem musi być osiągniecie porozumienia z polskim społeczeństwem. Nie zrażając się pesymistycznymi uprzedzeniami o bezowocności wszelkich tego rodzaju dążeń, chcemy ze społeczeństwem polskim pokoju na zasadzie porozumienia i wzajemnego szacunku, bo tylko pokój może nam dać możliwości życia ${ }^{35}$.

Władze polskie przyjęły wobec tej oferty postawę wyczekującą. Dla ogółu ruchu niemieckiego oznaczała ona rozbicie i stwarzała dla „Volksbundu” płaszczyznę jednoczenia Niemców pod wyznawanymi hasłami, czyli po linii polityki Rzeszy.

Na początku roku 1934 r. wystąpienia publiczne Panta nacechowane są potępieniem przejmowania przez mniejszość niemiecką na Górnym Śląsku tego co „modne” w Rzeszy i szerzenia tej ideologii wśród ogółu w zakładanych przez „Volksbund" świetlicach, nawet tam, gdzie procent Niemców jest mały po to tyl-

\footnotetext{
${ }^{32}$ Tamże, k. 113.

${ }^{33}$ Tamże, k. 176.

${ }^{34}$ Tamże, k. 241, 243.

${ }^{35}$ Tamże, s. 267.
} 
ko, by zakłócać ich lojalne współżycie z Polakami. Wywołało to koncentryczny atak na Panta ze strony VB i DP, nawołujących do bojkotu spotkań z nim, jako z przewodniczącym klubu niemieckiego w Sejmie Śląskim. Sytuację zaostrzyło powołanie przez Panta nowego pisma „Der Deutsche in Polen”. Podział w łonie mniejszości niemieckiej był faktem dokonanym. Front biegł między współdziałającymi VB i DP oraz osobno, ale w tym samy kierunku nastawioną FDP oraz DChVP i socjalistami przeciwnikami tych kierunków. Władze zauważają werbalną lojalność wobec Polski wszystkich ugrupowań, ale jako szczere widzą tylko stanowisko Panta ${ }^{36}$.

Propaganda hitlerowska weszła w 1934 r. w nową fazę. Spory lokalne marginalizuje się, dlatego JDP z nich się wyłączyła, stawiając sobie za cel sfaszyzowanie całej niemieckiej mniejszości. Porozumienie z DP przeciw DChVP ma na celu odseparowanie się od niemieckich katolików, będących w ocenie tych partii, podatnymi na polonizację. Polemikę w tym duchu podjęła nawet „Kattowitzer Zeitung". W ocenie władz, co wyraża sprawozdanie, Pant słabnie, mając tego świadomość, DChVP topnieje, a kierunek narodowosocjalistyczny przybiera na sile ${ }^{37}$.

Sprawozdanie z listopada $1934 \mathrm{r}$. informuje o powstaniu w Warszawie naczelnej organizacji niemieckiej pod nazwą „Rat der Deutschen in Polen”. Stanowisko opozycyjne zajęły wobec niej niemieccy socjaliści, JDP, a także Pant ${ }^{38}$.

W sprawozdaniu grudniowym 1934 r. odnotowano bezczynność i brak poczynań organizacyjnych DChVP i wyraźne oznaki uległości wobec tendencji „,ujednolicenia" czyli wpływów z Rzeszy. Panta na stanowisku przewodniczącego VdK zastąpił Otto Olbrich.

W styczniu 1935 r., mimo usunięcia Panta z przewodniczenia VdK w sprawozdaniu pojawia się sporo optymizmu. Wprawdzie stwierdzono w sprawozdaniu, że VdK został „ujednolicony”, ale nie oznaczało to złożenie broni przez Panta. Przypuszczano nawet, że stworzy on jakąś inną organizację, na co mogło wskazywać przedrukowanie w „Der Deutsche in Polen” artykułu z emigracyjnego pisma niemieckiego wychodzącego w Holandii - „Der deutsche Weg" ${ }^{39}$. Pant jednak zgłosił tylko gotowość katolików śląskich do włączenia się w ogólnokrajową organizację katolicką, opozycyjną w stosunku do narodowego socjalizmu, o ile takowa powstanie. W $1935 \mathrm{r}$. stwierdza się w sprawozdaniu ożywioną działalność VdK, także na gruncie młodzieżowym, gdzie inicjatywę przejął $\mathrm{Olbrich}^{40}$.

Szczególne znaczenie miało marcowe (1935) walne zebranie DChVP. Bezwład cechujący to stowarzyszenie widoczny był w zestawieniu jego agend. Natomiast wystąpienie Panta odzwierciedlało nastroje panujące wśród mniejszości niemieckiej na Śląsku lub nawet w ogóle w Polsce. Pant zrelacjonował pogłoski na temat możliwego powrotu Górnego Śląska do Niemiec, na co mogło wska-

${ }^{36}$ Tamże, sygn. 575, sprawozdania z początku roku 1934, s. 11, 36.

${ }^{37}$ Tamże, sprawozdanie z marca 1934, k. 57-58.

${ }^{38}$ Tamże, k. 235. „Rat der Deuschen in Polen” była organizacją dachową, mając zjednoczyć wszystkie ugrupowania niemieckie w Polsce, co było sprzeczne z celami poszczególnych społeczności mniejszościowych.

${ }^{39}$ Istniało w latach 1934-1940, redagowane przez jezuitę o. Friedricha Muckermanna.

${ }^{40}$ Tamże, sygn. 576, k. 22. 
zywać niedawne zajęcia Okręgu Saary. Pant przypomniał, o skutkach traktatu o nieagresji między Polską a Rzeszą z 1934 r., co wyklucza jakiekolwiek zmiany granic na przestrzeni 10 lat. Pant skrytykował władze polskie za ich liberalizm w taktowaniu wystąpień hitlerowców w Polsce. Nie przewidywał również długiej przyjaźni między Polską a III Rzeszą, dlatego ostrzegał Niemców w Polsce przed udziałem w manifestacjach na cześć Niemiec hitlerowskich, gdyż Polska je tylko dopuszcza, ale ich nie uznaje. Poza DChVP uznano, iż wszystkie ugrupowania mniejszościowe uległy już hitleryzmowi, nie wyłączając ,Zentralausschuss der Deutschen in Polen", którego szef, senator Erwin Hasbach chciał w 1935 r. zawrzeć z Pantem porozumienie pod warunkiem, że ten zaprzestanie krytyki narodowego socjalizmu. Ten jednak odmówił. Na płaszczyźnie stosunku do tej ideologii zbliżyły się do siebie DP i JDP ${ }^{41}$.

Taki stan marazmu w łonie DChVP odnotowuje się także w 1935 r. Pant ograniczał się do publicystyki na łamach „Der Deutsche in Polen”42.

W 1935 r. (sprawozdanie z sierpnia) odnotowano dalsze zaostrzenie konfliktu środowiska katolickiego, z walnym udziałem Panta, z resztą środowisk mniejszościowych. Pant ustąpił ze wszystkich stanowisk w VB, demaskując tę grupę na łamach swego pisma, jako pozbawioną oblicza politycznego i moralnego, zatem odmawiając jej prawa do reprezentowania całej społeczności niemieckiej. Proponował stworzenie organizacji zdolnej do wypełniania takiego zadania, $\mathrm{w}$ czym znalazł poparcie socjalistów. Pant był krytykowany przez VB jako zdrajca, co skłoniło „Zentralausschuss der Deutschen i Polen” do rezygnacji ze współpracy z Pantem. W rezultacie mógł on działać tylko na gruncie DChV, gdzie uzyskał votum zaufania. JDP unikająca identyfikacji z jakimkolwiek ugrupowaniem mniejszościowym, gdyż uznawała wyłącznie swą podległość władzom w Rzeszy, ale dotąd przychylnie ustosunkowana do Panta, zmieniła kurs na zbliżenie do DP. Władze polskie widzą w tym wyraźny ślad sterowania mniejszości niemieckiej z Rzeszy ${ }^{43}$.

Sprawozdanie wrześniowe 1935 r. przynosi informacje o rozbiciu w łonie katolickich organizacji niemieckich, konkretnie w „Jugend-und Jungmännerverein”, gdzie ujawnia się grupa członków JDP usiłująca ideologię nazistowską wprowadzać do związku. Jednocześnie odnotowano bardzo wielkie ożywienie we wszystkich katolickich organizacjach niemieckich ${ }^{44}$.

W listopadzie 1935 r. odnotowano w sprawozdaniu wzmożenie działalności VB w zakresie ruchu młodzieżowego i pomocy zimowej. W ostatniej dziedzinie udało się nawet pozyskać do współpracy niektóre organizacje katolickie, w tym VdK, „Katholischer Frauenbund" ${ }^{45}$.

W 1936 r. katolicka mniejszość niemiecka na Śląsku, znajdowała się coraz bardziej w defensywie, chociaż w sprawozdaniu z listopada 1936 r. określono VdK jako najpoważniejszą organizację niemiecką na Śląsku, względem organi-

\footnotetext{
${ }^{41}$ Tamże, sygn. 5761.63.

${ }^{42}$ Tamże, k. 255, i sygn. 576, Sprawozdania z 1935, k. 15.

${ }^{43}$ Tamże, sygn. 575, k. 164-165, 185.

${ }^{44}$ Tamże, sygn. 576, k. 179.

${ }^{45}$ Tamże, k. 209.
} 
zacyjnym i aktywności. Na potwierdzenie tej opinii przytoczono rodzaje i pola działalności, zwłaszcza sekcji młodzieżowej, np. zespoły śpiewacze, teatralne, tzw. Heimatabendy - w sumie 1.085 imprez $^{46}$.

Ożywienie w organizacjach niemieckich obserwuje się od początku roku 1936, co przypisywano częściowo kontaktom ze Śląskiem Opolskim. Zaznaczyła się inicjatywa „Volksbundu”, który skupia wokół siebie takie organizacje, jak DP, „Deutscher Volksblock” oraz JDP współzawodniczącą o wpływy. Współzawodnictwo między tymi grupami nie osłabia ich ekspansji w kierunku „ujednolicenia" życia Niemców w duchu narodowosocjalistycznym i stworzenia jednego ugrupowania niemieckiego. W tym celu nawiązywane są kontakty z mniejszością niemiecką w Wielkopolsce i na Pomorzu. W działaniu na rzecz „ujednolicenia” przoduje JDP. W przeciwieństwie do wymienionych ugrupowań organizacje katolickie, jak DChVP, podobnie zresztą jak „Deutsche Sozialistische Arbeiterpartei” nie wykazują aktywności ${ }^{47}$. Taki stan rzeczy potwierdza sprawozdanie z lutego 1936 r., podkreślając jednak niesłabnącą polemikę Panta z polityką JDP i ,Volksbundu” oraz z ideologią nazistowską na łamach „Der Deutsche in Polen”"48.

W sprawozdaniu z marca 1936 r. zaznacza się wysiłki DChVP, partii w międzyczasie liczącej zaledwie 2.000 członków, zwalczającej wpływy narodowosocjalistyczne, zwłaszcza w związku z wykryciem na Śląsku tajnych komórek NSDAP. Kuria diecezjalna w Katowicach włącza się w tę działalność, organizując nabożeństwa i odczyty demaskujące błędy w ideologii narodowego socjalizmu. Ks. Franz Wosnitza, zwracając się do katolickich organizacji młodzieżowych, podkreślał wobec wykrycia komórek NSDAP, apolityczność katolickiego ruchu młodzieżowego. Każdego, kto należałby do NSDAP należy wykluczyć z tych organizacji ${ }^{49}$.

W sprawozdaniu z marca i kwietnia 1936 r. zwrócono uwagę na silną akcję werbunkową w VdK skierowaną do młodzieży i tworzenie kół młodzieżowych. $\mathrm{W}$ referacie na walnym zebraniu powiedziano m.in., że związek nie chce być stowarzyszeniem wyznaniowym, lecz chce brać udział w tworzeniu wspólnoty narodowej i przeżywać radość wraz z rodakami w ojczyźnie z powodu „odrodzenia” dokonującego się w kraju. W maju VdK został przyjęty do „Rat der Deutschen in Polen", co Pant uważa za chęć zniwelowania jego wpływów w VdK, a nadto widzi w tym krok różnoznaczny z „ujednoliceniem” obozu niemieckiego. Faktem jest jednak też, że DChVP w dalszym ciągu przeżywa kryzys ${ }^{50}$.

W sprawozdaniu lipcowym z 1936 r. zawarta jest informacja o pogłoskach jakoby zbierał on wiadomości na temat działalności gestapo w województwie śląskim z zamiarem przekazania ich władzom. Prawdopodobnie wiedza UWŚl. na

${ }^{46}$ Tamże, sygn. 577, k. 219. Sprawozdanie za listopad 1936.

${ }^{47}$ Tamże, k. 8, 13.

${ }^{48}$ Tamże, k. 30.

${ }^{49}$ Tamże, k. 39-41.

${ }^{50}$ Tamże, k. 75-77 i 95. Brak aktywności DChVP mógł wynikać z trudności w znalezieniu wspólnego języka katolików i protestantów. 
ten temat była rozleglejsza, gdyż zaznaczono, że szczegóły zostaną dostarczone do odpowiedniego ministerstwa osobno ${ }^{51}$.

Sprawozdanie z listopada 1936 r. relacjonuje zebranie walne DChVP. Liczba członków spadła do 1.300. Partia traci na znaczeniu i jest zwalczana nie tylko przez jej niemieckich przeciwników, ale także przez związki zawodowe. Pant w przemówieniu powiedział, że triumf narodowego socjalizmu na tym terenie, to upadek tutejszych Niemców. Polemizująca z tym „Kattowitzer Zeitung” odkryła ostatecznie swe oblicze.

W styczniowym sprawozdaniu 1937 r. znalazła się informacja o planach DChVP utworzenia nowej organizacji dla Niemców za granicą pod nazwą „Deutscher Verband zur Nationalen Befriedigung” z siedziba we Wiedniu. „Kattowitzer Zeitung" z miejsca oceniła tę inicjatywę Panta jako tworzenia organizacji jawnie antyhitlerowskiej ${ }^{52}$.

W lutym 1937 r. w sprawozdaniu poddano analizie reakcję środowisk niemieckich na deklarację płk Adama Koca wygłoszoną 21 II 1937 r. przez radio ${ }^{53}$. Treść deklaracji najbardziej odpowiadała polityce Panta, który w artykule Der Weg der Venunft stwierdza

zasady deklaracji płk Koca w ramach stosunku wzajemnego narodu polskiego o niemieckiego, narodów ościennych oraz stosunku pomiędzy tymi mniejszościami a państwem przyjmujemy bez zastrzeżeń.

Z kolei JDP zareagowała w swym organie „Der Aufbruch”, zasłaniając się przemówieniem senatora Wiesnera. Stwierdzono, iż stanowisko Koca pokrywa się ze stanowiskiem senatora Wiesnera przedstawionym na posiedzeniu Senatu w dniu 5 III 1937 r. Bardziej powściągliwy był organ VB „Kattowitzer Zeitung”, dostrzegając jedynie pewne elementy deklaracji jako pozytywne w stosunku do mniejszości niemieckiej ${ }^{54}$.

W sprawozdaniu za marzec i kwiecień 1937 r. dominuje wystąpienie nadprezydenta prowincji śląskiej Prus, Josefa Wagnera ${ }^{55}$ i reakcja na nie dr Panta. Wagner wypowiadał się na temat mniejszości polskiej w Niemczech i niemieckiej

${ }^{51}$ Tamże, k. 130.

52 Tamże, sygn. 578, k. 14.

${ }^{53}$ Deklaracja ideowo-polityczna obozu tworzonego przez pułk. Adama Koca [Obóz Zjednoczenia Narodowego - OZON - SB.] „Naród i Wojsko”, Organ Centralny Federacji Polskich Związków Obrońców Ojczyzny. Rok IV, nr 9, 27 II 1937, s. 1-3. Sprawę mniejszości narodowej poruszał punkt 9. „Wytyczną naszą w stosunku do mniejszości narodowych jest chęć bratniego współżycia obywatelskiego na tej ziemi, za którą w ciągu wieków przelewaliśmy krew, zakładając ogniska cywilizacji i broniąc ich przed zalewem barbarzyństwa. W historycznych procesach splotły się nasze losy. W nasze współżycie wbijały się kliny interesów obcych dla nas i dla nich. Po latach wspólnej niedoli znaleźliśmy się znowu w ramach jednej Rzeczypospolitej. Zdajemy sobie sprawę z odrębności stanowiących różnicę między nimi i nami. Uznajemy te odrębności, jak długo nie godzą w interesy państwa i o ile nie są rozmyślnie wyzyskiwane dla wznoszenia między nami muru chińskiego i gruntowania nienawiści”.

${ }^{54}$ Tamże, k. 34.

${ }^{55}$ Był to działacz nazistowski, w III Rzeszy gauleiter NSDAP tej prowincji, w latach 1938-1941 także nadprezydent Prowincji Górnośląskiej. 
w Polsce. Pant zwracał uwagę na niestosowność reprezentowania mniejszości niemieckiej przez polityków z Rzeszy. Stwierdza, że Wiesner i Hasbach aprobują każde posunięcie rządu Rzeszy, natomiast wielu Niemców nie życzy sobie, żeby ich interesy były reprezentowane z Berlina, gdyż okazuje się, że w ten sposób urzędnicy Rzeszy narzucają się jako ich adwokaci.

Krytycznie odniesiono się do wszczętej przez Panta akcji na rzecz utworzenia nowej organizacji pod nazwą „Verband der Deustchen in Polen” mającej skupiać wszystkich Niemców w Polsce, będących przeciwnikami ruchu hitlerowskiego, a zwolennikami ściślej i szczerej współpracy z narodem gospodarzy. Ze względu na małą popularność Panta i jego słabnące wpływy we własnym środowisku, uznano inicjatywę za nierokującą sukcesu i niewartą poparcia ${ }^{56}$.

W sprawozdaniu z czerwca i września 1937 r. relacja z walnego zjazdu VdK z całej Polski. W sumie liczy związek 26.796 członków, w tym z województwa śląskiego 13.000. Również DChVP odbyła walny zjazd. Organizacja liczy na Górnym Śląsku 890 członków ${ }^{57}$. Jej stan finansowy skłonił do likwidacji lokalu i przyjęcia siedziby w miejscu redakcji „Der Deustche in Polen”58.

Sprawozdanie z października 1938 r. przynosi wiadomość o śmierci w dniu 20 października Eduarda Panta i o postępującym uwiądzie DChVP, której jedyną inicjatywą było wezwanie do udziału w wyborach do sejmu i senatu. Wprawdzie podjęto w tej partii jeszcze próbę rozszerzenia jej agend dla Śląsk Cieszyński, ale bez powodzenia ${ }^{59}$.

W 1938 r. odnotowano w sprawozdaniu listopadowym podjętą przez VDK akcję mającą na celu walkę o utrzymaniu niemieckich nabożeństw, likwidowanych w niektórych miejscach, według władz kościelnych, z powodu zmniejszania się liczby w nich uczestniczących. Władze VdK w swych odezwach prasowych w tej sprawie wprawdzie nie kwestionują tego uzasadnienia, ale wzywają katolików niemieckich do udziału w nabożeństwach w ich języku, co jest nie tylko obowiązkiem religijnym, ale także narodowym ${ }^{60}$.

Sprawozdanie z 1939 r. przynosi wieści o malejącym zaangażowaniu organizacyjnym mniejszości niemieckiej, nawet tak prężnych organizacji, jak JDP. Niektóre organizacje, jak DChVP i związki socjalistyczne, już od pewnego czasu w ogóle nie są aktywne. Od marca 1939 r. odczuwa się panujące wśród Niemców przekonanie, że Śląsk wkrótce wróci do Niemiec. Stąd zalecenia ostrożności w działaniu organizacji mniejszościowych, co widać w działaniu VB. Wyraźnie unika się prowokowania Polaków, żeby nie ściągnąć na siebie represji. Obserwuje się też wiele ucieczek z terenu województwa śląskiego do Rzeszy ${ }^{61}$.

\footnotetext{
${ }^{56}$ WAPK, UWŚl. Sygn. 578, k. 60, 77.

${ }^{57}$ Tamże, k. 125, 176.

${ }^{58}$ Tamże, k. 130.

${ }^{59}$ UWŚl. Sygn. 579, k. 161.

${ }^{60}$ Tamże. Sprawozdanie z listopada 1938.

${ }^{61}$ WAPK, UWŚl. sygn. 580. Sprawozdanie z maja 1939.
} 
$* * * *$

W relacjonowaniu sprawozdań sytuacyjnych władz województwa śląskiego za okres 1933-1939 zwrócono uwagę na zachowanie się społeczeństwa niemieckiego tworzącego związki i stowarzyszenia różnych odcieni i opcji politycznych. Powstaje na podstawie takiego materiału obraz przedstawiający ewolucję w postawie Niemców na Śląsku idącą w dwóch kierunkach. Jeden znaczony irredentą i czerpaniem nie tylko inspiracji, ale wręcz dyrektyw i środków finansowych z Republiki Weimarskiej a później z Rzeszy oraz drugi kierunek mniej lub bardziej nastawiony na autonomiczną w stosunku do celów politycznych Niemiec politykę tej części mniejszości, co wymagało lojalnego włączenia się w rzeczywistość polską. Najczęściej wymienia się jako orędownika tego kierunku dr Eduarda Panta. Możliwości pójścia tą samą drogą istniały jednak także w innych ugrupowaniach, zwłaszcza katolickich. Sytuacja zmieniała się w miarę jak reżim hitlerowski rozpoczął drogę ku wojnie. W tym przypadku opozycja wobec Hitlera w społeczeństwie niemieckim faktycznie stopniowo zamierała, a większość Niemców poza granicami Rzeszy uznała pójście za Hitlerem jako swój obowiązek patriotyczny, co wcale nie musiało oznaczać ich identyfikacji ze światopoglądem nazistowskim. Sprawozdania, a raczej ich fragmenty tu wykorzystane, niewiele mówią o realiach życia mniejszości niemieckiej w polskiej rzeczywistości. Dlatego też, aby w części je ukazać streścimy poniżej memoriał wojewody Michała Grażyńskiego zawierający obraz oparty na faktach, a nie na życzeniach i skargach, jaki jawi się w świetle ówczesnych mediów i różnego rodzaju interpelacji Niemców, ewentualnie także polemik z nimi władz lokalnych .

\section{Memorial wojewody Grażyńskiego sygnowany przez niego, bez tytułu i daty, na temat stosunków wśród mniejszości niemieckiej na Górnym Śląsku ${ }^{62}$}

Traktaty mniejszościowe miały na celu zapewnienie wszechstronnego rozwoju mniejszości, a nie budzenie nastrojów irredenty, braku lojalności wobec państwa i umożliwianie mniejszości bycia narzędziem w rękach państwa ościennego. Akcja sterowana z Niemiec nie ma nic wspólnego z ochroną mniejszości. Celem Niemiec jest utrzymanie nastroju antywersalskiego $i$ atakowanie granicy wschodniej. Duża wojowniczość zebrań w Niemczech, nawet wypowiedzi Hindenburga, ukierunkowana przeciwko Polsce. Wielki wpływ tych enuncjacji na mniejszość denerwuje Polaków i podnieca Niemców, prowadząc do zderzeń i zamącając współżycie. Narzędzie: nieustanne, nieuzasadnione protesty do Ligi Narodów, byle podtrzymać punkty zapalne. Niemcy starają się zebrać materiał świadczący o płynności przekonań narodowych na Górnym Śląsku i terrorze stosowanym przeciwko ludności niemieckiej lub sprzyjającej Niemcom przez władze polskie. Wskazówki i częściowo środki idą z Berlina. Kierownikiem akcji na terenie województwa śląskiego jest Volksbund, w teorii broni spraw kulturalnych, gospodarczych, socjalnych mniejszości niemieckiej, ale w rzeczywistości stwarza afekty

${ }^{62}$ Memoriał nie jest datowany, ale jego treść w dużej części pokrywa się z artykułem dr Eustachego Noszczyńskiego Egzaminy językowe dzieci zgłaszanych do szkół niemieckich na Ślasku, noszącym datę: październik 1938. Instytut Śląski w Katowicach seria III Komunikat 34. 
polityczne potrzebne polityce Berlina. Wyolbrzymianie drobnych zadrażnień to ważne narzędzie. Akcja Volksbundu celowo torpeduje pacyfikację stosunków i służy celom rewizjonistycznym. Stwierdzono, że najwybitniejsi jej członkowie uprawiali szpiegostwo wojskowe. N. P. Andrzej Dudek, Gertruda Ernst, Bruno Thomas, Śmiałek Karol, Stuchlik Leonard. Ci skazani, a inni zwolnieni z braku dowodów. Volksbund jest w stałym kontakcie z Konsulatem Generalnym w Katowicach, z Deutsches Auslands-Institut w Stuttgarcie. Kierownik Volksbundu, Ulitz oskarżony o wysyłanie poborowych do Niemiec, by uchronić ich od służby w WP. Nauczyciele niemieccy dostają dodatki specjalne do pensji pochodzące z Niemiec, konspiracyjnie za pomocą centrali w Bytomiu. Volksbund pomaga w uzależnianiu robotników polskich od Niemców przez to, że odpowiednio wyzyskuje fakt, iż tysiące pracują w niemieckich zakładach po stronie niemieckiej. O faktycznym zasięgu niemczyzny świadczą najlepiej statystyki szkolne. Do mniejszościowych szkół powszechnych uczęszcza niespełna 12\% dzieci, a w 1 . i 2. roku nauczania liczba ta jest jeszcze mniejsza, bo 7.5\%. Niemcy korzystając właśnie z uzależnień socjalno-ekonomicznych werbują tak przy wyborach, jak i do szkół w miejscowościach, gdzie nikt nigdy nie mówił po niemiecku. Egzamin Maurera wyraźnie odkrył mistyfikację ${ }^{63}$. Dywersja Volksbundu przy zbieraniu wniosków o przyjęcie do szkoły mniejszościowej ma na celu pokazanie zasięgu niemczyzny. Państwo ma obowiązek przestrzegać umów międzynarodowych chroniących mniejszości, ale ma też obowiązek obronienia swych obywateli przed terrorem narodowościowym. Nie stosują go władze, ale właśnie pośrednio Volksbund nakłaniając do szkoły mniejszościowej.

W górnośląskiej części województwa śląskiego istniało w zakresie szkolnictwa powszechnego w dniu 1 X 1926 r. 77 szkół publicznych liczących 266 klas w 357 oddziałach o liczbie dzieci 17.374 w czym uprawnionych do uczęszczania na podstawie artykułu 106 Konwencji Genewskiej 16.389 dzieci, dzieci z innych związków szkolnych 67, obywateli państw obcych 918 z czego niemieckich 863, komunalnych szkół wydzielonych 2 z 19 klasami o 45 oddziałach mających ogólnie 1.900 uczniów z czego obywateli polskich 1.768 (miejscowych 1.394, zamiejscowych 374), obywateli państw obcych 132, z czego niemieckich 105, prywatnych szkół powszechnych 11 o 37 klasach w 41 oddziałach mających 1205 uczniów, z czego obywateli polskich 1.103, obcych 102 w tym Niemów 97. Z całego szkolnictwa wydziałowego dla mniejszości niemieckiej cyfry są następujące: szkół 90, klas 322 w 343 oddziałach, uczniów 2.479, w tym obywateli obcych 1.152, a w szczególności niemieckich 1.065. Na jeden oddział przeciętnie 47 dzieci, a w szkołach polskich 500 . W szkłach prywatnych przeciętna wynosi 30. w tym rodzaju szkół istnieją szkoły karłowate z 16 uczniami.

${ }^{63} \mathrm{~W}$ celu zakończenia sporu o szkoły wszczynanego przez mniejszość niemiecką w Polsce Rada Ligi Narodów decyzją a dnia 12 III 1927 powołała do życia instytucję egzaminów językowych. Jej zadaniem było zbadanie czy dzieci zgłoszone do szkół niemieckich mówią faktycznie językiem niemieckim w takim stopniu, aby mogły bez przeszkód pobierać naukę w tym języku. Egzamin w tym względzie przeprowadzał ekspert szwajcarski Maurer, stwierdzając, że prawie połowa zgłoszonych dzieci nie władała dostatecznie językiem niemieckim. Por. Noszczyński, Egzaminy językowe dzieci, s. 3. 
Gimnazjów i liceów dla mniejszości niemieckiej na Śląsku jest 6 publicznych i 9 prywatnych. W 6 publicznych jest 1.775 uczniów, w tym obywateli państw obcych 75 , w prywatnych 1.676 , w tym obywateli państw obcych 141. Młodzieży gimnazjalnej mniejszościowej razem 2.851, w tym obywateli państw obcych 216 z czego Niemców 188.

Szkoły powszechne i gimnazja mniejszościowe mają odpowiednią ilość nauczycieli. W szkołach powszechnych $431 \mathrm{w}$ gimnazjach 182, należących w 80 procentach do mniejszości narodowej niemieckiej, gdyż nauczyciele Polacy zatrudnieni są tylko do nauki języka polskiego. Szkoły mniejszościowe mieszczą się w tych samych budynkach, co szkoły polskie lub w osobnych zawsze prawie w lepszych warunkach niż szkoły polskie. Polskie władze są liberalne. Na Śląsku opolskim dzieci polskie nie mają wcale szkolnictwa, a ludności polskiej jest około pół miliona. Do tzw. szkół polskich chodzi zaledwie 506 dzieci. Propaganda niemiecka Volksbundu zmierza do zaabsorbowania Ligi Narodów błahymi sporami, by przemycić to o co głównie chodzi, tzn. wciągniecie do szkól mniejszościowych dzieci większościowe. Dążą więc do rozszerzenia art. 106 Konwencji Genewskiej, jakoby oświadczenie o języku dziecka miało być objawieniem subiektywnej woli osoby odpowiedzialnej za wychowanie dziecka do jakiej szkoły chce je posłać. Trybunał w Hadze wyrokiem z 26 IV 1928 wyraźnie stwierdził, że ma to być oświadczenie obiektywne, a tym samym przekreślił wywody niemieckie.

Dziś Volksbund kwestionuje ważność egzaminów dokonanych przez eksperta pedagogicznego wyrokiem haskim z r. 1927/28, twierdząc, że zostały unieważnione wyroki haskie. Kwestionuje też czy orzeczenia prezydenta Komisji Mieszanej oparte na wynikach egzaminów z obu mają znaczenie wobec późniejszych oświadczeń osób odpowiedzialnych za wychowanie swych dzieci, że te nauczyły się potem po niemiecku, czyli wprowadza znów pojęcie subiektywności. Dlaczego to czyni odpowiadają cyfry: z dzieci wpisanych na rok 1926/27 przeegzaminował ekspert 964. Na podstawie wyników tego egzaminu przeznaczył prezydent Komisji Mieszanej do szkoły niemieckiej 441 t.j. 46\%, wykluczył od niej 523 t.j. 54\%. Dzieci wpisanych na rok 1927/1928 egzaminował ekspert 721, z czego 433 do szkoły mniejszościowej - 60\% 288 wykluczonych (40\%). Ogółem z 1685 dzieci egzaminowanych uznał ekspert i prezydent Komisji Mieszanej 874, 51\% za władające dostatecznie językiem niemieckim, a 811 - 48\% za nie nadające się do szkoły mniejszościowej. Egzaminy Maurera stwierdziły, że w szkole mniejszościowej znalazło się 800 dzieci nie umiejących po niemiecku, a więc należące do większości polskiej ${ }^{64}$.

\section{$* * * *$}

Walka o szkolę będącą pod wpływem organizacji politycznych mniejszości niemieckiej miała na celu nie tylko zapewnienie uczniom narodowości niemieckiej edukacji w ich ojczystym języku, ale w praktyce wychowywała ona nie tyle do życia w Polsce, co raczej do warunków panujących w Rzeszy. Była ona także narzędziem walki z polonizacją, dlatego zależało Niemcom na wprowadzenie

${ }^{64}$ WAPK, UWŚl. sygn.266 k. 15-27. 
do szkoły niemieckiej także dzieci i młodzież z polskich rodzin górnośląskich. Jak tego dowiodły egzaminy Maurera około połowy dzieci zgłaszanych do szkól mniejszościowych miało jako język ojczysty i faktycznie używany, polski.

Problem szkół mniejszościowych jest tylko jednym, choć może najważniejszym, punktów spornych, jakie prokurowała mniejszość niemiecka w województwie śląskim. Zważywszy kierunki ideowe i polityczne obecne w tym województwie wśród żyjącej tam ludności niemieckiej nasuwa się właściwie tylko jeden wniosek. Jeśli nie jej ogół, to większość przywódców w ciągu całego dwudziestolecia pracowała na rzecz irredenty. Stanowiła obce ciało w organizmie, jakim było państwo polskie, dające im jako obywatelom prawo i sposobność do rozwoju i wspólnego budowania polskiej rzeczywistości. Problem polegał na tym, że chcieli oni budować niemiecką, uznając państwowość polską jako twór przejściowy.

słowa kluczowe: Górny Śląsk, mniejszość niemiecka, II Rzeczpospolita, Urząd Wojewódzki Śląska, Michał Grażyński

\section{BIBLIOGRAFIA}

\section{Źródla}

Wojewódzkie Archiwum Państwowe w Katowicach (WAPK)

Urząd Wojewódzki Śląski, sygn. 571, Sprawozdanie sytuacyjne (styczeń-kwiecień) 1931, $\mathrm{k}, 56,151-152,218$.

WAPK, sygn. 571, Sprawozdania sytuacyjne z (lipiec-grudzień) 1931, k.21, 49-56, 79.

WAPK, sygn. 573, Sprawozdanie sytuacyjne z 1932 r., k. 52-56, 80,160, 190, 220, 247.

WAPK, sygn. 573, Sprawozdanie sytuacyjne (czerwiec-lipiec) 1932, k. 200-391.

WAPK, sygn. 574, k. 32.

WAPK, sygn. 574, Sprawozdanie sytuacyjne z maja 1933, k. 65, 113, 116-117,142, 148, $176,241,243,267$.

WAPK, sygn. 575, Sprawozdanie sytuacyjne z początku roku 1934, k. 11, 36.

WAPK, sygn. 575, Sprawozdanie sytuacyjne z marca 1934, k.57-58, 164-165, 185.

WAPK, sygn. 576, Sprawozdanie sytuacyjne z marca 1934, k. 22, 63, 255.

WAPK, sygn. 576, Sprawozdanie sytuacyjne z wrzesnia 1935, k. 179, 209.

WAPK, sygn. 577, Sprawozdanie sytuacyjne z listopada 1936, k. 8, 13, 30, 39-40, 75-77 i $95,130,219$,

WAPK, sygn. 578, Sprawozdanie sytuacyjne ze stycznia1937, k. 14, 34.

WAPK, sygn. 578, Sprawozdanie sytuacyjne z marca 1937, k. 60, 77, 125, 130, 176.

WAPK, sygn. 579, Sprawozdanie sytuacyjne z listopada 1938 [b.n.k]

WAPK, sygn. 580, Sprawozdanie sytuacyjne z maja 1939 [b.n.k]

WAPK, sygn. 266, Memoriał wojewody Grażyńskiego, k. 15-27.

Dziennik Ustaw 1932 nr 94, s. 1947, poz. 808 Rozporządzenia Prezydenta Rzeczypospolitej z dnia 27 X 2932. Prawo o stowarzyszeniach. 
Deklaracja ideowo-polityczna obozu tworzonego przez pułk. Adama Koca, „Naród i Wojsko”, Organ Centralny Federacji Polskich Związków Obrońców Ojczyzny, 4(1937) 9, s. 1-3.

\section{Opracowania}

Deutsche und Polen zwischen den Weltkriegen. Minderheitssituation und Volkstumskampf im Grenzgebiet. Amtliche Berichterstattungen aus beiden Ländern 1920-1939, opr. M. Niendorf i P. Hauser, Monachium i in. 1997.

Kierski Kazimierz, Ochrona praw mniejszości w Polsce, Poznań 1933.

Kucharczyk Barbara, W polityce wojewody śląskiego Michała Grażyńskiego wobec mniejszości niemieckiej na Górnym Śląsku, Częstochowa 2011.

Maciejewski Marek, Prawne aspekty położenia mniejszości narodowych na Górnym Śląsku w latach 1918-1939, „Czasopismo Prawno-Historyczne”, 65 (2013) nr1, s. 249269.

Margielewicz Marek, Problem świadomości zagrożenia ze strony Niemiec w społeczeństwie polskim na Górnym Śląsku w ostatnich latach II Rzeczypospolitej, „Wieki stare i nowe, 1 (16) 2009, s. 264-292.

Noszczyński Eustachy, Egzaminy językowe dzieci zgłaszanych do szkół niemieckich na Śląsku, w: Komunikat Instytutu Śląskiego w Katowicach seria III Komunikat 34 z 1938 r., s. 1-7.

Olszar Henryk, Duchowieństwo katolickie diecezji śląskiej (katowickiej) w Drugiej Rzeczypospolitej, Katowice 2000.

Orzechowski Marian, Wojciech Korfanty, Biografia polityczna, Wrocław-Warszawa-Kraków-Gdańsk 1978.

Rechowicz Henryk, Wojewoda śląski dr Michał Grażyński, Warszawa 1988.

Wardzyńska Maria, Był rok 1939. Operacje niemieckiej policji bezpieczeństwa w Polsce. Intelligenzaktion, Warszawa 2009.

Zieliński Władysław, Polska i niemiecka propaganda plebiscytowa na Górnym Śląsku, Wrocław-Warszawa-Kraków-Gdańsk 1972.

Zieliński Zygmunt, Educatrix et Advocata. Wychowawca i Obrońca. Miejsce Kościoła w dziejach Narodu, Lublin 2014.

Zieliński Zygmunt, Kościół w kręgu rzeczywistości politycznej, Lublin 2003.

\section{Internet}

Lutosławski Jakub, Mniejszość niemiecka w Polsce jako instrument rewizjonistycznej polityki w latach 1918-1939. www.archivia.com.pl/.../mniejszosc-niemiecka-w-polsce-jako-instrument-rewizjonisty (dostęp: 20.07.2016). 


\title{
SITUATION REPORTS OF THE SILESIA PROVINCIAL GOVERNOR'S OFFICE IN THE YEARS 1933-1939 AS THE SOURCE FOR THE ACTIVITY OF THE ASSOCIATIONS OF THE GERMAN MINORITY IN THE SILESIA PROVINCE
}

\begin{abstract}
Summary
The coverage of the situation reports of the Silesian authorities for the period 19331939 highlighted the behaviour of German society involved in creating unions and associations of various shades and political options. This material depicts the picture with the evolution in the attitude of the Germans in Silesia going in two directions. One is marked with irredentism and deriving not only inspiration, but also directives and financial resources from the Weimar Republic and later the Reich. The other direction was more or less oriented towards the autonomous policy (in relation to the political objectives of the German policy) of the part of the minority, which required loyal inclusion in the Polish reality. The most often mentioned advocate of the latter direction was Dr Eduard Pant. The possibilities of following the same road were also in other groupings, especially Catholic ones. The situation changed as the Nazi regime began the road to war. In this case, the opposition to Hitler in German society actually was gradually dying; a majority of the Germans outside the Reich decided to follow Hitler as their patriotic duty, which did not have to mean they identified with the Nazi world-view.
\end{abstract}

Keywords: Upper Silesia, the German minority, situation reports, Silesia Provincial Governor's Office, Michał Grażyński 